\title{
Review of "Rise and fall of the carbon civilisation: resolving global environmental and resource problems" by Patrick Moriarty and Damon Honnery
}

\author{
Felix Witing and Daniela Thrän*
}

Moriarty, Patrick and Honnery, Damon

Rise and fall of the carbon civilisation: resolving global environmental and resource problems

London, Dordrecht, Heidelberg, New York: SpringerVerlag; 2011.

218 pages, ISBN 978-1-84996-482-1

The concentration of carbon dioxide in the atmosphere is now the highest that it has ever been for nearly one million years, and potentially much longer. Various solutions have been proposed, which shall move us to a carbon-neutral civilisation to avoid a dangerous climatic change and also to be responsive to the future depletion of conventional fossil fuel. Within this book, most of the important technical mitigation solutions are presented in a comprehensive, well-structured way. Furthermore, the authors discuss the widespread and excessive technological optimism and show that no combination of technical mitigation solutions will lead to an ecologically sustainable society if economic growth continues.

The first chapter introduces the problems that arise during the transformation of a carbon-driven civilisation into a carbon-neutral one. It is shown that there are numerous limitations when considering the limited time available in an increasingly uncertain future. Technological realism and new economic approaches are required. One reason for the need for transformation, the global climate change, is reviewed in Chapter 2. Not only the science and impacts of global warming but also the possibilities to mitigate global warming and to adapt to the changes are discussed. Chapter 3 underlines the limited availability of natural resources and fossil fuels. The authors argue that human demands have probably already exceeded the bio-capacity of the earth. The expanding environmental pollution is

\footnotetext{
* Correspondence: Daniela.thraen@ufz.de

Department Bioenergie, Helmholtz-Zentrum für Umweltforschung (UFZ), Leipzig 04347, Germany
}

also steadily reducing this capacity. A global population of over nine billion by 2050 , along with rising-per-capita incomes, will put a tremendous pressure on ecosystem services and mineral reserves. However, it is also pointed out in Chapter 4 that problems and prognoses regarding the global environment and resource estimates are always subject to many uncertainties. Chapter 5 provides an overview of renewable energy resources. These can be divided into two groups: continuously (e.g., biomass and geothermal resources) and intermittently (e.g., solar and wind) available renewables. The authors argue that currently, the full technical potential for replacing fossil fuels is only focusing on the variety of intermittent sources. That is why further solutions are required to store and to convert renewable energy into other energy forms (e.g., hydrogen). A historical and technical introduction to nuclear energy is presented in Chapter 6. The future of this form of energy production is uncertain. Thermal reactors are seen as a dead-end technology, and the construction of new reactors can be very cost-intensive due to reactor safety issues. For further development of this branch, however, many more breeder reactors will be required. Another important aspect to achieve our climate goals discussed in Chapter 7 is the efficient energy production and savings on energy consumption. While the possibilities for increasing the efficiency of energy production are limited, there are great potentials and also a need for energy savings. Chapter 8 gives an overview of natural and technical forms of carbon sequestration. Technical solutions such as carbon capture and sequestration or air capture have either a very limited effect or heavy energy costs. The need to permanently bury captured $\mathrm{CO}_{2}$ adds further limits to these options. More futuristic and desperate measures are discussed in Chapter 9. Here, the possibilities of geoengineering by manipulating global and regional albedos are discussed along with the risks of unwanted impacts on climate (e.g., lower 
precipitation) and ocean levels (e.g., acidification). Also, ethical and political difficulties are shown. Provided that we want to limit the global temperature rise to $2^{\circ} \mathrm{C}$, the authors finally estimate the available sustainable global energy supply in Chapter 10. According to this, in 2050, a total of about 300 EJ could be available, which is about $33 \mathrm{GJ}(1.05 \mathrm{~kW})$ per person or less than half of the current world average. A change in the global economy towards a human needs approach will be necessary.

Key aspects of global environmental and resource problems and their technical mitigation solutions are considered in this book. It provides a valuable background for anybody who is interested in global climate change and its challenges. In a very instructive way, even amateurs will obtain an overview of what the possible strategies are to solve these current problems. For students, technical professionals, and researchers in the fields of environmental and energy sciences, as well as politicians, this book provides a well-structured overview and a lot of valuable references to continue their study.

\section{Competing interests}

Both authors declare that they have no competing interest.

\section{Authors' contributions}

DT conceived of the book review and participated in its design and coordination. FW carried out the review and drafted the manuscript. Both authors read and approved the final manuscript.

Received: 7 August 2012 Accepted: 8 August 2012

Published: 28 August 2012

doi:10.1186/2192-0567-2-17

Cite this article as: Witing and Thrän: Review of "Rise and fall of the carbon civilisation: resolving global environmental and resource problems" by Patrick Moriarty and Damon Honnery. Energy, Sustainability and Society 2012 2:17.

\section{Submit your manuscript to a SpringerOpen ${ }^{\circ}$ journal and benefit from:}

- Convenient online submission

- Rigorous peer review

- Immediate publication on acceptance

- Open access: articles freely available online

- High visibility within the field

- Retaining the copyright to your article

Submit your next manuscript at $>$ springeropen.com 